\title{
Effects of pyrethroid insecticides on subjects engaged in packaging pyrethroids
}

\author{
F HE, ,' J SUN, ${ }^{2}$ K HAN,' Y WU, ' P YAO,' S WANG,' L LIU' \\ From the Institute of Occupational Medicine,' Chinese Academy of Preventive Medicine, Beijing, and the \\ Institute of Occupational Health of Hebei Province, ${ }^{2}$ Shijiazhuang, Hebei, People's Republic of China
}

ABSTRACT A health survey was conducted on 199 workers engaged in dividing and packaging pyrethroids. The subjects were exposed to fenvalerate at $0.012-0.055 \mathrm{mg} / \mathrm{m}^{3}$ and deltamethrin at $0.005-0.012 \mathrm{mg} / \mathrm{m}^{3}$ in the air with simultaneous skin contact for $0.5-4.5$ months. Burning sensations and tightness or numbness on the face appeared in two thirds of the subjects and one third had sniffs and sneezes. Abnormal facial sensations, dizziness, fatigue, and miliary red papules on the skin were more evident in summer than in winter. Neither abnormalities in other organs or systems nor symptoms or signs of acute pyrethroid poisoning were found by interviews, examinations, and laboratory tests. There was no significant difference in plasma levels of NA, cAMP, and cGMP between the examined subjects and the control group. The urine concentration of fenvalerate in the study group ranged from 1.02 to $18.6 \mu \mathrm{g} / \mathrm{l}$; deltamethrin in the urine was present in trace amounts.

Importation and application of pyrethroid insecticides for pest control in China have increased. By comparison with commonly applied broad spectrum insecticides such as organophosphates and carbamates, synthetic pyrethroids have a high insecticidal activity and a low toxicity in mammals. They are rapidly metabolised and leave virtually no residue in the biosphere. ${ }^{1}$ They are therefore used to control a wide variety of agricultural pests and to protect stored products. At present, the most popularly used pyrethroids in cotton fields are deltamethrin, fenvalerate, and cypermethrin. To facilitate the application of these insecticides by individual farmers, the imported barrelled pyrethroids are divided and packaged into $100 \mathrm{ml}$ bottles in several small pesticide factories. Since there is little information concerning human chronic exposure to synthetic pyrethroids, the purpose of the present study was to investigate the effects of pyrethroids on occupationally exposed subjects engaged in dividing and packaging pyrethroid insecticides.

\section{Material and methods}

EXPOSURE BACKGROUND

Work procedure

The whole process of dividing, packaging, and repack-

Accepted 14 August 1987 aging pyrethroids was completed by hand. The imported barrelled $2.5 \%$ deltamethrin emulsion (RousselUclaf Company), $20 \%$ fenvalerate emulsion (Suimoto Company), or $10 \%$ cypermethrin emulsion (Shell Oil Company) were alternately poured into containers from which the pyrethroid emulsion flowed through rubber tubes to fill $100 \mathrm{ml}$ bottles. About 50000 bottles a day were filled up and packed in boxes. All work was conducted over a period of four to five months on two occasions - in late winter and during the summer. The workers wore rubber gloves and gauze masks only in winter and had more cutaneous exposure in summer to pyrethroids, mainly fenvalerate and deltamethrin. There was no mechanical ventilation or air conditioning in the workshops. The air concentration of the solvent vehicle (xylene) was lower than $100 \mathrm{mg} / \mathrm{m}^{3}$ but the smell of xylene could be detected.

\section{Analyses of fenvalerate and deltamethrin in air samples}

Air was sampled two to 12 times for each sampling place in two workshops with an air flow of $2-10 \mathrm{l} / \mathrm{min}$ in 1983 and 1984. Fenvalerate and deltamethrin in air were collected on polyester or glass fibre filters and then extracted with n-hexane and determined by gas chromatography with $63 \mathrm{Ni}$ electron capture detector. A varian $\mathbf{3 7 0 0}$ gas chromatograph was used equipped with a 3\% OV-101/Chromosob WAW DMCS 60-80 mesh, $1 \mathrm{~m} \pm 2 \mathrm{~mm}$ column at $240^{\circ} \mathrm{C}$. The detection limit was $2 \mathrm{ng} / \mathrm{ml}$ hexane. 
Table 1 General aspects of the two groups exposed to pyrethoids and the reference group

\begin{tabular}{|c|c|c|c|c|c|c|}
\hline \multirow[b]{2}{*}{ Group } & \multirow{2}{*}{$\begin{array}{l}\text { Total No of } \\
\text { subjects }\end{array}$} & \multicolumn{2}{|c|}{ Sex } & \multirow{2}{*}{$\begin{array}{l}\text { Median of age } \\
\text { (years) }\end{array}$} & \multicolumn{2}{|c|}{$\begin{array}{l}\text { Duration of exposure } \\
\text { (months) }\end{array}$} \\
\hline & & $M$ & $F$ & & Mean & Range \\
\hline $\begin{array}{l}\text { Exposed to pyrethroid } \\
\text { Summer group } \\
\text { Winter group } \\
\text { Controls }\end{array}$ & $\begin{array}{r}199 \\
87 \\
112 \\
46\end{array}$ & $\begin{array}{l}52 \\
25 \\
27 \\
22\end{array}$ & $\begin{array}{r}147 \\
62 \\
85 \\
24\end{array}$ & $\begin{array}{l}20 \cdot 4 \\
20 \cdot 4 \\
20 \cdot 5 \\
19 \cdot 2\end{array}$ & $\begin{array}{l}3 \cdot 0 \\
2 \cdot 5 \\
3 \cdot 3 \\
-\end{array}$ & $\begin{array}{l}0 \cdot 5-4 \cdot 5 \\
0 \cdot 5-4 \cdot 5 \\
0 \cdot 5-4 \cdot 5 \\
-\end{array}$ \\
\hline
\end{tabular}

MEDICAL EXAMINATIONS

\section{Subjects}

Two groups of subjects exposed to pyrethroids were studied-in July 1983 (summer group) and in March 1984 (winter group). The total number of subjects was 199. Forty six students without exposure to pesticides were also examined to serve as a reference group. Table 1 shows the general aspects of the three groups.

\section{Methods}

Clinical examination-All subjects were interviewed and given questionnaires about their occupational history, past illness, previous exposure to pesticides, and present symptoms. Physical and neurological examinations, electrocardiogram and laboratory tests including blood haemoglobin and white cell count, routine urine tests, and serum glutamic pyruvic transaminase were carried out. Further investigations included (a) radioenzymatic assay of plasma noradrenaline (NA) in 27 controls and 73 subjects of the winter group, among whom $70 \%$ had been exposed for at least four months; and $(b)$ radioimmunoassay for plasma guanosine 3', 5'-cyclic phosphate (cGMP) and cyclic aminomonophosphate (cAMP) in five controls and 10 subjects exposed to pyrethroids randomly chosen from those having been examined on plasma NA.

Analyses of fenvalerate and deltamethrin in urineTwenty four hour urine or morning urine samples were collected in polyvinyl bottles rinsed by $1 \mathrm{~N}$ HCL from 22 subjects during exposure to fenvalerate or deltamethrin. A Beckman 344 high performance liquid chromatograph with a detection limit at $4 \mu \mathrm{g} / 1$ was used for the analysis of deltamethrin in seven workers. The same gas chromatographic system as described above was used for analysis of urinary fenvalerate in five workers and for analyses of both urine deltamethrin and fenvalerate (detection limit of both were $0.2 \mu \mathrm{g} / 1$ using $10 \mathrm{ml}$ urine sample) in 10 workers.

\section{Results}

AIR CONCENTRATION OF PYRETHROIDS

Table 2 shows the results of determination of fenvalerate and deltamethrin in air samples.

\section{CLINICAL FEATURES}

Two thirds of the subjects from both groups exposed to pyrethroids developed abnormal facial sensation that was described as feelings of burning, tingling, itching, tightness, or numbness (table 3 ). The facial sensory symptoms in most cases (107 subjects) appeared after half an hour's exposure and lasted no longer than 24 hours. The cheeks and periorbital areas were most frequently and symmetrically affected despite wearing gauze masks. The facial burning or tingling sensation was often exacerbated by sweating or washing with warm water. Sneezing and increased nasal secretion were also temporarily present at work and were more often seen in the winter group. Systemic symptoms such as dizziness, fatigue, or nausea were subtle or mild. On examination, red miliary papules with mild itching were found in $14.1 \%$ of the subjects mainly on the face and chest, occasionally on the girdle area and perineum, but seldom on the hands. The abnormal facial sensation, dizziness, and fatigue and the red miliary papules were all more frequently seen in the summer group than the winter group ( $\mathrm{p}<0.05)$.

The 44 workers who had had previous exposure to deltamethrin or fenvalerate in fields or workshops and had had transient abnormal facial sensation six months before developed similar symptoms during current exposure. But in only one of the five subjects who had previously had miliary papules due to exposure to pyrethroids did the skin changes appear.

There were no clinical signs of acute pyrethroid poisoning such as headache, fasiculations, and convulsions (F $\mathrm{He}$ et al, XXI International Congress on

Table 2 Air concentrations of fenvalerate and deltamethrin

\begin{tabular}{|c|c|c|c|}
\hline \multirow[b]{2}{*}{ Date } & \multirow{2}{*}{$\begin{array}{l}\text { Room } \\
\text { temperature } \\
\left({ }^{\circ} \mathrm{C}\right)\end{array}$} & \multicolumn{2}{|c|}{ Mean concentration ( $\left.\mathrm{mg} / \mathrm{m}^{3}\right)$} \\
\hline & & Fenvalerate & Deltamethrin \\
\hline $\begin{array}{l}\text { June } 1983 \\
\text { March } 1984\end{array}$ & $\begin{array}{r}25-30 \\
9-10\end{array}$ & \multirow{2}{*}{$\begin{array}{l}0.012 \pm 0.0006 \dagger \\
0.051 \pm 0.007 \dagger \\
0.055 \pm 0.0134 \ddagger \\
0.013 \pm 0.004 \dagger \ddagger\end{array}$} & $\begin{array}{l}0.012 \pm 0.001 \ddagger \\
\S\end{array}$ \\
\hline May $1984^{*}$ & $24-27$ & & $0.005 \pm 0.001$ \\
\hline
\end{tabular}


Table 3 Symptoms and signs of subjects exposed to pyrethroids*

\begin{tabular}{|c|c|c|c|c|c|c|}
\hline \multirow[b]{2}{*}{$\begin{array}{l}\text { Symptoms } \\
\text { and signs }\end{array}$} & \multicolumn{3}{|l|}{ No of subjects } & \multicolumn{3}{|c|}{ Percentage (\%) } \\
\hline & $\begin{array}{l}\text { Summer group } \\
(n=87)\end{array}$ & $\begin{array}{l}\text { Winter group } \\
(n=112)\end{array}$ & $\begin{array}{l}\text { Total } \\
(n=199)\end{array}$ & $\begin{array}{l}\text { Summer } \\
\text { group }\end{array}$ & $\begin{array}{l}\text { Winter } \\
\text { group }\end{array}$ & Total \\
\hline $\begin{array}{l}\text { Abnormal facial sensations } \\
\text { Sneezing and increased }\end{array}$ & 80 & 60 & 140 & 91.9 & $53 \cdot 6$ & $70 \cdot 4$ \\
\hline $\begin{array}{l}\text { nasal secretion } \\
\text { Dizziness } \\
\text { Fatigue } \\
\text { Nausea } \\
\text { Red miliary papules }\end{array}$ & $\begin{array}{l}14 \\
24 \\
17 \\
16 \\
20\end{array}$ & $\begin{array}{r}50 \\
5 \\
1 \\
5 \\
8\end{array}$ & $\begin{array}{l}64 \\
29 \\
18 \\
21 \\
28\end{array}$ & $\begin{array}{l}16 \cdot 1 \\
27 \cdot 6 \\
19 \cdot 5 \\
18 \cdot 3 \\
22 \cdot 9\end{array}$ & $\begin{array}{r}44 \cdot 6 \\
4 \cdot 5 \\
0 \cdot 9 \\
4 \cdot 5 \\
7 \cdot 1\end{array}$ & $\begin{array}{r}32 \cdot 1 \\
14 \cdot 5 \\
9 \cdot 0 \\
10 \cdot 5 \\
14 \cdot 1\end{array}$ \\
\hline
\end{tabular}

*All the symptoms and signs listed in table 3 showed statistically significant difference between the two groups by $\chi^{2}$ test (p $\left.<0.05\right)$.

Occupational Health, Dublin, 1984). Nor were abnormalities of blood, heart, lungs, liver, kidneys, and nervous system found by physical examinations or laboratory tests in either of the exposed groups. No menstrual changes were noted in female workers.

The levels of plasma NA, cGMP, and cAMP in the exposed subjects were all in the normal range compared with the reference group (table 4).

\section{BIOLOGICAL MONITORING}

The amount of fenvalerate in urine determined in five workers exposed to fenvalerate at $0.055 \pm 0.013 \mathrm{mg} / \mathrm{m}^{3}$ for 4.5 months was $1.02-18.6 \mu \mathrm{g} / \mathrm{l}$ by gas chromatography. After cessation of dividing and packaging fenvalerate for five days, the urinary fenvalerate was still detectable at $0 \cdot 2-0.7 \mu \mathrm{g} / 1$ in eight out of 10 workers, although the air concentration of fenvalerate was $0.013 \pm 0.004 \quad \mathrm{mg} / \mathrm{m}^{3}$. Urinary deltamethrin concentrations in 17 exposed subjects were in trace amounts using either gas chromatography or high performance liquid chromatography (table 5).

\section{Discussion}

The increased use of pyrethroid insecticides in recent years has established them as a major class of pesticide chemicals. Yet few data are to be found concerning the ffects of human exposure. Le Quesne and Maxwell first reported that 19 of 23 workers exposed to cypermethrin, permethrin, and fenvalerate experienced episodes of abnormal facial sensation without neurological and

Table 4 Plasma levels of plasma noradrenaline (NA), plasma guanosine $3^{\prime}, 5^{\prime}$-cyclic phosphate (cGMP), and cyclic aminomonophosphate $(c A M P)^{*}$

\begin{tabular}{|c|c|c|c|c|}
\hline & \multicolumn{2}{|c|}{$\begin{array}{l}\text { Pyrethroids exposed } \\
\text { subjects winter group }\end{array}$} & \multicolumn{2}{|c|}{ Reference group } \\
\hline & No & $M e a n \pm S D$ & $\overline{N o}$ & $M e a n \pm S D$ \\
\hline $\begin{array}{l}\text { NA (ng/ml) } \\
\text { cAMP (pmol/ml) } \\
\text { cGMP (pmol/ml) }\end{array}$ & $\begin{array}{l}73 \\
10 \\
10\end{array}$ & $\begin{array}{cl}0.4171 & \pm 0 \cdot 1055 \\
44.24 & \pm 14.07 \\
5.99 & \pm 2.13\end{array}$ & $\begin{array}{r}27 \\
5 \\
5\end{array}$ & $\begin{aligned} 0.452 & \pm 0.0930 \\
44.70 & \pm 8.99 \\
6.36 & \pm 1.72\end{aligned}$ \\
\hline
\end{tabular}

*All data showed no significant difference between the two groups by $t$ test $(\mathrm{p}>0.05)$. electrophysiological abnormalities in the arms and legs. ${ }^{2}$ Kolmodin-Hedman et al found irritative symptoms from the skin and the upper respiratory tract in planters handling fenvalerate and permethrin both in wettable powder and emulsion. ${ }^{3}$ The cutaneous sensation was also noted in about a third of agricultural fenvalerate applicators by Tucker and Flannigan. ${ }^{4}$ Recently acute deltamethrin poisoning (F He, 1984) and dermatitis with vesiculation and red miliary papules due to exposure to deltamethrin in farmers were reported in China.

In the present study the most prominent symptom in subjects engaged in dividing and packaging fenvalerate, deltamethrin, and cypermethrin was transient abnormal facial sensation. The second symptom was sneezing or increased nasal secretion. The systemic symptoms were mild and the red itching miliary papules were the only abnormal signs in $14 \%$ of the exposed subjects. Although the air concentration of pyrethroids in the dividing and packaging workshops was lower in the summer than in the winter because of increased ventilation by opening the doors and windows, the facial sensory symptoms, systemic symptoms, and skin papules were more often seen in subjects in the summer group. This may be due to more cutaneous exposure to pyrethroids in summer because the workers did not use protective gloves for climatic reasons and tended to sweat more. The rashes that occasionally appeared on the girdle area or perineum seemed to result from direct topical skin contact with pyrethroids from contaminated hands.

It is of interest to ascertain whether the burning and tingling facial sensation reported by the exposed subjects was an irritative skin reaction or a sign of peripheral sensory nerve involvement. In most of our subjects this sensory symptom was noted mainly on the face but not on the hands and other exposed areas and was not associated with papules. There was about a 30 minute latent period for the development of the sensation and it generally lasted no longer than 24 hours. Moreover, direct contact with the pyrethroid emulsion was not necessary to induce the paraesthaesias. All these characteristics seem to differ from an irritative skin reaction. On the other hand, all pyrethroids are lipophilic compounds with a low vapour 
Table 5 Urinary fenvalerate and deltamethrin concentrations in exposed subjects

\begin{tabular}{|c|c|c|c|c|c|}
\hline & \multicolumn{4}{|c|}{ Urine } & \multirow[b]{3}{*}{ Air concentrations $\left(\mathrm{mg} / \mathrm{m}^{3}\right)$} \\
\hline & \multicolumn{2}{|c|}{ Gas chromatography } & \multicolumn{2}{|c|}{ Liquid high performance chromatography } & \\
\hline & No & $\mu g / l$ & No & $\mu g / l$ & \\
\hline Fenvalerate & $\begin{array}{l}5 \\
8^{*} \\
2^{*}\end{array}$ & $\begin{array}{l}1.02-18.6 \\
0.2-0.7 \\
<0.2\end{array}$ & & & $\begin{array}{l}0.055 \pm 0.0134 \\
0.013 \pm 0.004 \\
0.013 \pm 0.004\end{array}$ \\
\hline Deltamethrin & $\begin{array}{r}4 \\
10\end{array}$ & $\begin{array}{r}0.3-0.8 \\
<0.2\end{array}$ & 7 & 4 & $\begin{array}{l}0.012 \pm 0.001 \\
0.005 \pm 0.001\end{array}$ \\
\hline
\end{tabular}

* No simultaneous skin exposure to fenvalerate.

pressure and are practically insoluble in water. It was believed that cutaneous exposure to aerosol or vapour was responsible for several of the reported cases. But the solvent was not the likely cause because the abnormal facial sensation appeared when all types of pyrethroid products were used, including wettable powders. ${ }^{3}$ The insecticidal activity of the pyrethroids is due to their neurotoxicity. They interact with $\mathrm{Na}^{+}$ channels in excitable membranes causing a prolongation of the transient increase in sodium permeability and the sensory organs will produce trains of impulses rather than a single nerve impulse after treatment with pyrethroid. ${ }^{56}$ It may be postulated that the facial sensory symptoms are most likely to be due to transient lowering of the threshold of sensations of facial skin sensory nerve endings after exposure to pyrethroids. This would be similar to the phenomena that have been described after exposure of animal nerves to pyrethroids. ${ }^{2}$

Cremer and Seville reported that the type 2 syndrome, particularly choreoathetotic writhing induced by deltamethrin in rat, was associated with unusually high concentrations of plasma noradrenaline and adrenalin compared with other stressful conditions. ${ }^{7}$ Cerebellar cGMP was also raised to 10 times those in control animals during the deltamethrin induced motor syndrome. ${ }^{8}$ In the present study neither manifestations of acute pyrethroid poisoning nor significant changes of plasma NA, CGMP, and cAMP were found.

In five workers exposed to fenvalerate at levels of $0.055 \pm 0.0134 \mathrm{mg} / \mathrm{m}^{3}$ with simultaneous skin contact with the same pyrethroids for 0.5-4.5 months urinary fenvalerate levels determined by gas chromatography were $1.02-18.6 \mu \mathrm{g} / \mathrm{l}$. When the air concentration of fenvalerate was lowered to $0.013 \pm 0.004 \mathrm{mg} / \mathrm{m}^{3}$ after the dividing and packaging of fenvalerate was stopped for five days, the urinary fenvalerate concentration was still detectable at $0 \cdot 2-0.7 \mu \mathrm{g} / \mathrm{l}$ in eight of the 10 workers. This indicates that it is necessary to minimise exposure. By contrast, all the urinary deltamethrin concentrations determined in 17 exposed workers were lower than the detection limit of both gas chromatography $(0.2 \mu \mathrm{g} / \mathrm{l})$ and high performance liquid chromatography $(4 \mu \mathrm{g} / \mathrm{l})$. The reason for this, other than lower air concentration of deltamethrin, is the rapid metabolism of deltamethrin. Ruzo et al showed that $98-99 \%$ of deltamethrin was excreted in rats on the eighth day after dosing'; it is advisable to develop methods for measuring metabolites of deltamethrin in the urine ${ }^{10}$ to investigate the uptake and metabolism of deltamethrin in man further.

We are grateful to Drs Denggui Li and Hongtao Zhang for their help with various aspects of the study. We acknowledge our indebtedness to Dr Guangjing Zhu from the Institute of Basic Medical Sciences, Chinese Academy of Medical Sciences, for detecting the plasma NA, cAMP, and cGMP.

Requests for reprints to: Professor Fengsheng He, Institute of Occupational Medicine, Chinese Academy of Preventive Medicine, 29 Nan Wei Road, Beijing, People's Republic of China.

\section{References}

1 Knox JM, Tucker SB, Flannigan SA. Parasthesia from cutaneous exposure to a synthetic pyrethroid insecticide. Arch Dermatol 1984;120:744-6.

2 Le Quesne PM, Maxwell IC. Transient facial sensory symptoms following exposure to synthetic pyrethroids: a clinical and electrophysiological assessment. Neurotoxicology 1980;2:1-11.

3 Kolmodin-Hedman B, Swensson $\AA$, Akerblom M. Occupational exposure to some synthetic pyrethroids (permethrin and fenvalerate). Arch Toxicol 1982;50:27-33.

4 Tucker SB, Flannigan SA. Cutaneous effects from occupational exposure to fenvalerate. Arch Toxicol 1983;54:195-202.

5 Parkin PJ, Le Quesne PM. Effect of a synthetic pyrethroid deltamethrin on excitability changes following a nerve impulse. J Neurol Neurosurg Psychiatry 1982;45:337-42.

6 Vijverberg HPM, Bercken JVD. Action of pyrethroid insecticides on the vertebrate nervous system. Neuropathol Appl Neurobiol 1982;8:421-40.

7 Cremer JE, Seville MP. Comparative effects of two pyrethroids, deltamethrin and cismethrin, on plasma catecholamines and on blood glucose and lactate. Toxicol Appl Pharmacol 1982;66:124-33.

8 Brodie ME, Aldridge WN. Elevated cerebellar cyclic GMP levels during the deltamethrin-induced motor syndrome. Neurobehav Toxicol Teratol 1982;4:109-13.

9 Ruzo LO, Engel JL, Casida JE. Deltamethrin metabolites from oxidative, hydrolytic and conjugative reactions in mice. Journal of Agricultural Food and Chemistry 1979;27:725-31.

10 Eadsforth CV, Baldwin MK. Human dose-excretion with the pyrethroid insecticide, cypermethrin. Xenobiotica 1983;13: 67-72. 